\title{
A game proposal for teaching math operations to 6th / 9th grade students
}

Uma proposta de jogo para o ensino das operações matemáticas aos alunos do $6^{\circ} / 9^{\circ}$ ano

Una propuesta de juego para enseñar operaciones matemáticas a estudiantes de sexto / noveno grado

Gustavo Nogueira Dias ORCID: https://orcid.org/0000-0003-1315-9443 Colégio Federal Ten. Rêgo Barros, Brazil

E-mail: gustavonogueiradias@gmail.com

Yann Sávio de Souza Belleza ORCID:https://orcid.org/0000-0002-9186-5514 Universidade da Amazônia, Brazil Email: savio_95@outlook.com

Carlos Mairton Barreto Saraiva ORCID: https://orcid.org/0000-0002-2870-5462 Universidade da Amazônia, Brazil Email: carlosmairton1@gmail.com

Edith Gonçalves Costa ORCID: https://orcid.org/0000-0003-0724-3243 Secretaria de Educação do Estado do Pará, Brazil Email: costaedith15@gmail.com

Gerson Pompeu Pinto

ORCID: https://orcid.org/0000-0002-6740-4507 Colégio Federal Ten. Rêgo Barros, Brazil E-mail: gersonpompeu@gmail.com

Pedro Roberto Sousa da Silva ORCID: https://orcid.org/0000-0003-1780-5705 Escola de Aplicação da Universidade Federal do Pará, Brazil E-mail: prof.pedromat@hotmail.com

Fernando Ramos de Farias

ORCID: https://orcid.org/0000-0001-8357-9684 Colégio Federal Ten. Rêgo Barros, Brazil E-mail: fernandorf.math@gmail.com

Adenilson Pereira Bonfim

ORCID: https://orcid.org/0000-0002-9354-7384

Colégio Federal Ten. Rêgo Barros, Brazil

Email: adenilsonctrb@gmail.com

Aneliza Alves Silva de Farias

ORCID: https://orcid.org/0000-0002-8471-4830

Secretaria de Educação do Estado do Pará, Brazil

Email: anelizasilva@hotmail.com

Wagner Davy Lucas Barreto

ORCID: https://orcid.org/0000-0002-0675-9005

Colégio Federal Ten. Rêgo Barros, Brazil E-mail: profwlucas@yahoo.com.br

Washington Luiz Pedrosa da Silva Junior

ORCID: https://orcid.org/0000-0002-1413-0047

Colégio Federal Ten. Rêgo Barros, Brazil E-mail: jwl_pedrosa@hotmail.com

José Carlos Barros de Souza Júnior ORCID: https://orcid.org/0000-0003-4465-8237

Colégio Federal Ten. Rêgo Barros, Brazil Email: barrosctrb@gmail.com

Gilberto Emanoel Reis Vogado ORCID: https://orcid.org/0000-0003-4763-4767 Universidade do Estado do Pará, Brazil E-mail: gvogado@globo.com

Vanessa Mayara Souza Pamplona ORCID: https://orcid.org/0000-0002-2461-2103 Universidade Federal Rural da Amazônia, Brazil E-mail: vanessamayara2@gmail.com 


\author{
Alessandra Epifanio Rodrigues \\ ORCID: https://orcid.org/0000-0002-8375-2923 \\ Universidade Federal Rural da Amazônia, Brazil \\ E-mail: alessandra.epifanio@ufra.edu.br \\ Herson Oliveira da Rocha \\ ORCID: https://orcid.org/0000-0002-2494-6277 \\ Universidade Federal Rural da Amazônia, Brazil \\ E-mail herson@ufra.edu.br \\ Fabricio da Silva Lobato \\ ORCID: https://orcid.org/0000-0002-8240-8039 \\ Universidade do Estado do Pará, Brazil \\ E-mail: fabriciolobatomat15@hotmail.com
}

\begin{abstract}
The purpose of this work is to serve as an aid tool for the teacher, for the students and for the development of the classes, however, we hope that the game is developed in an appropriate way so that it does not harm their performance. The objective of this work is to analyze the possibilities of teaching / learning of mathematical operations from the application of the game "the awakening of mathematics" for 6th and 9th grade students. The work methodology was developed for the students in order to solve such difficulties that some students were presenting during the math classes, developed from cardboard paper, A4 paper in 9x9 square format (9 squares in height and width), containing a total of 81 cells on the board, where the mental calculation of the four mathematical operations is proposed. It was realized that the use of the game should not be applied only as a means of interaction between students, therefore, if the teacher proposes the game as a teaching strategy, he should treat it as a vehicle for building knowledge, creating and experimenting.
\end{abstract}

Keyword: Game; Mathematical operation; Teaching strategy.

\title{
Resumo
}

O presente trabalho tem por finalidade servir como um instrumento de auxílio para o professor, para os alunos e para o desenvolvimento das aulas, entretanto, esperarmos que o jogo seja desenvolvido de formar adequada para que não prejudique o desempenho dos mesmos. O objetivo deste trabalho é Analisar as possibilidades de ensino/aprendizagem das operações matemáticas a partir da aplicação do jogo "o despertar da matemática" para alunos do $6^{\circ}$ e $9^{\circ}$ ano. A metodologia de trabalho foi desenvolvida para os alunos a fim de solucionar tais dificuldades que alguns alunos estavam apresentando no decorrer das aulas de matemática, desenvolvido de papel cartolina, papel A4 em formato quadrangular 9x9 (9 quadrados na altura e na largura), contendo um total de 81 células no tabuleiro, onde se propõe o cálculo mental das quatro operações matemáticas. Foi percebido que o uso do jogo não deve ser aplicado apenas como um meio de interação entre os alunos, portanto, se o professor propuser o jogo como uma estratégia de ensino, deverá tratar como um veículo de construção do conhecimento, de criação e de experimentação.

Palavras-chave: Jogo; Operação matemática; Estratégia de ensino.

\section{Resumen}

El propósito de este trabajo es servir como herramienta de ayuda para el docente, para los alumnos y para el desarrollo de las clases, sin embargo, esperamos que el juego se desarrolle de manera adecuada para que no perjudique su desempeño. El objetivo de este trabajo es analizar las posibilidades de enseñanza / aprendizaje de operaciones matemáticas a partir de la aplicación del juego "El despertar de las matemáticas" para alumnos de $6^{\circ}$ y $9^{\circ}$ grado. La metodología de trabajo fue desarrollada para los estudiantes con el fin de resolver las dificultades que algunos estudiantes estaban presentando durante las clases de matemáticas, desarrollada a partir de papel cartón, papel A4 en formato cuadrado 9x9 (9 cuadrados de alto y ancho), conteniendo un total de 81 celdas en el tablero, donde se propone el cálculo mental de las cuatro operaciones matemáticas. Se comprendió que el uso del juego no debe aplicarse solo como un medio de interacción entre los alumnos, por lo tanto, si el docente propone el juego como estrategia de enseñanza, debe tratarlo como un vehículo para construir conocimiento, crear y experimentar.

Palabras clave: Juego; Operación matemática; Estrategia docente.

\section{Introduction}

Teaching mathematics is not just passing on content to students, it is developing logical reasoning, stimulating independent thinking, developing other forms of creativity and the ability to solve problems.

There is a long discussion about the problems encountered in teaching and learning mathematical content, for teaching such content to students it is necessary to have an innovative methodological proposal, which helps the teacher in the classroom as well as students in the construction of their mathematical knowledge . 
The use of the game in the classroom during mathematics classes can be a methodological, pleasurable and effective resource for student teaching / learning. The game as a didactic resource can bring to the student's teaching a broader, dynamic and interesting view regarding the study of mathematics, making the classes become attractive and challenging, showing that mathematics can be a facilitator for the development of the understanding of their respective content.

For Leontiev (1988), we are using the game not only as a material for instruction but using it in a way that incorporates teaching.

However, the game is not only intended to make classes more enjoyable or to teach a certain subject, but to be useful so that the teacher can identify which students are having difficulties in the process of understanding the subjects covered in the classroom, serving as $\mathrm{X}$-rays for learning.

The construction of such knowledge through the use of the mathematical game in the school environment brings many advantages, because, while the student is playing, he is doing it of his own free will and for leisure, reaching the results expected by the teacher.

We must realize that, not always, the resolution of exercises develops the student's capacity for autonomy.

For Kammi (1992), games involved rules and social interaction for the development of autonomy.

The game has to have the purpose of exploring the child in order to promote the transformation, to remove everything that is behind the learning. The social interaction of students for the practice of the game is very important for the coexistence of each one of them in society.

According to Malba Tahan (1968), "for games to produce the desired effects, they must, in a way, be directed by educators".

We cannot take the trouble to develop an activity with all the concepts and at the time of application, let the students be in charge of handling them themselves. It will be obvious that the activity will not deliver the expected results.

It is important to analyze, what are the teaching methods that will propose changes in the classes and that make the classes more dynamic. Amid the fun, the child gets involved in the game in a way to feel the need to share information with the other colleague acquiring constructivist knowledge. Although it assumes a player's stance in relation to the game, it builds affective relationships between opponents.

According to Miranda (2001), the didactic game can have several objectives to be achieved, related to cognition, affection, motivation and creativity.

However, meaningful learning of knowledge is facilitated when doing something fun and pleasurable, as students are encouraged when they receive the proposal for learning in a more fun way, resulting in significant learning.

For Kishimoto (1996), the game is not the end, but the axis that leads to a specific didactic content.

For many, the mathematical game can serve as a pass of time during classes, however, it has a fundamental importance that being properly explored will transform students and math classes.

The imposition of the relationship exposes the interior of the participants and affects their emotions, putting their limits into practice. Playing, playing, having fun, these are the most comprehensive ways to quote a new methodology of interdisciplinarity of the child with the mathematical game.

While the child is playing, he develops some skills that served as a basis for his professional training, such as: confidence, logical reasoning, stimulating independent thinking and criticality.

The game has no restrictions regarding the difficulties in calculations and it was not only imposed for leisure and interaction of students, it was added and conditioned to math classes with the intention of removing students' interest in learning mathematics. 
Therefore, the use of the game as a methodological form has been acquired in the classroom very slowly, since educators and students need time to get used to this new method. It is necessary for the teacher to be an information mediator in order to make students opinion makers.

There are many games that can be used in math classes: the ones already bought ready, the ones that need to be made manually and the virtual games.

All can be handled by the teacher and used by his students in the classroom while the content is being passed on, as it will change the daily routine of learning mathematics, attracting students' attention and dedication through differentiated dynamics. In this way, it is up to the teacher to analyze which of the types of games best adapt to the students and the intended content.

It is not enough that the teacher knows a variety of games and knows how to play them. It is necessary that he select the appropriate game according to the content he is passing on to the students and be able to dynamically and interactively combine this resource, in order to escape the traditional way of teaching and learning mathematics.

The fact that it is used for 6th grade students is due to the fact that it is the first year of the major elementary school and where the first mathematical properties and the calculation of numerical expressions, in a big way, where from now on the use of other more agile tools can give another meaning and relevant importance to these students.

Through our observations, we have an obligation to solve such difficulties that arose in the learning of some students and it will be through the use of a didactic resource that we will capture the self-confidence of some students who let themselves be carried away by the difficulties imposed by the so abstract mathematics.

Our didactic resource will not replace mathematics classes, but will serve as a support to facilitate students' learning and arouse their interest in mathematics.

This pleasant moment of relaxation, interaction and socialization between students can be used, working like this, with the necessary content in teams or in pairs, making the classroom more pleasant.

Regarding the objectives of this work, we can list:

Analyze the teaching / learning possibilities of mathematical operations from the application of the game "the awakening of mathematics" for 6th grade students / 9.

Develop the game.

$>$ Apply the game "the awakening of mathematics".

$>$ Analyze the teaching / learning possibilities of mathematical operations from the application of the game "the awakening of mathematics" for 6th grade students / 9.

\section{Theoretical Foundation}

There are several theorists who claim that the use of didactic games during classes will effectively collaborate for the development of students, therefore, these theorists not only affirm what they say about students about the construction of scientific knowledge and learning, however, in the development of social and cultural capacities that will end up contributing to the development of independent thinking. Before all authors who support the use of educational games, the following can be highlighted: Dewey (1952), Piaget (1976) and Vygotsky (2007).

The pillar that supports the defense of these theorists is that the use of educational games are fundamental resources for the students' learning process.

Any and all didactic games, no matter what their purpose, will be able to bring the child's imagination to reality, giving permission to the development of their creativity and skills. However, after the inclusion of the didactic game during 
classes, students would feel increasingly motivated to enter the mystified world of so mathematics, although, it seems abstract, we need didactic games to escape the traditional method of teaching and learning mathematics .

For Brito (2005), the application of a method would have to resemble nature and the use of games was also advised as a use, aiming at the formative value.

A didactic game cannot be elaborated in any way, we have to target the social class of each student, however, if the school is located in the urban area and there is a student in the classroom that belongs to the rural area, the game must have structures appropriate for both social classes.

For Dewey (1952), the world presents a vision of the whole and because of that children imprison it, although, that vision can be divided into two parts, from chaos to order.

The world is a school where you can learn different things, both good and bad, so we have to polish the child with good information. The child is a wise being who can capture such information in surprising ways, and it can be through communication or visual means.

Ferrari (2004) points out that, from the use of the game during classes, the knowledge that the child acquired must be explored in their experience.

In view of all the concepts that the didactic game should have, the exploration of experience is a fundamental point to be developed, since, from the students' experience, it is possible to discover what difficulties the student will be having in their daily life. Taking such acquired mathematical knowledge and applying it in their daily lives, will certainly make learning more coherent for students.

Drawing and playing should be preparatory stages for the development of children's written language. Educators must organize all these actions and the complex transition process from one type of written language to another. They must accompany this process through their critical moments to the point of discovering that it is possible to draw not only objects, but also speech. If we wanted to summarize all these practical demands and express them in a unified way, we could say what we should do is, teach children the written language and not just the writing of letters (Vygotsky, 2007, p.134).

According to the hypotheses of these theorists, it can be concluded that the inclusion of games during classes is linked to learning. Above all, it is possible to have an effective learning through the use of a didactic resource and the play, because the student will not only learn the proposed content by copying from the board or watching the teacher, above all, the fun awakens spirits and pleasures for discovery new knowledge.

While the child is playing he is freeing himself, that is, he has the freedom to think, create and criticize.

For Silveira (1998), games can be used in classes with different purposes and one of the important concepts for such purposes is the construction of self-confidence.

Not only do we want students to have fun while practicing the pedagogical activity, but to awaken concepts so that each student can develop the activity without having the fear of making mistakes and can apply it in their daily lives. Selfconfidence is a point that should be addressed by educators, because it will be the starting point of this concept that students will walk on their own.

Everyone will gain scientific and constructivist knowledge through the application of the mathematical game and not only the students for being receiving such knowledge, but we teachers and future teachers as well.

According to Moyles (2002), pedagogical games aim to promote teaching-learning situations and to increase the construction of knowledge. 
The game will not be imposed so that the teacher can occupy the time of his students, but to fill the void that some students in his class are having in the middle of his explanation.

Working with games requires planning actions when and how the game will be proposed, what are the possible explorations and interventions of the teacher so that there is learning and not just play.

For Batllore (2006), games are not included during classes just for the fun of students, but to achieve the desired learning objectives.

According to the author's words, we have to include games during classes to achieve the desired goals, not only apply them by applying more with goals to be beaten.

It is not a matter of including in the class the same game that the child plays at home, on the street or when participating in camps, but of looking for games and recreational activities that serve to achieve concrete learning objectives, acquisition of new knowledge, development of skills cognitive and social, etc. (Batllori, 2006 p.14).

Working with games requires planning actions when and how the game will be proposed, what are the possible explorations and interventions of the teacher so that there is learning and playing, but always aiming at the exploration of concrete learning objects.

The relevance of the work in the classroom has been seeking a better understanding, so that in the future, we will use this activity correctly, making the most of its use.

Today, there are several studies that claim that the use of educational games in teaching can collaborate effectively for students' learning.

The game is a teaching material when it promotes learning, facing the playful situations the student the logical structure and therefore the present content.

Today we already know that, associated with the playful dimension, is the educational dimension of the game. One of the most promising interfaces of this association concerns the consideration of errors. The game reduces the consequence of the player's mistakes and failures, allowing him to develop initiative, self-confidence and autonomy. Basically, the game is a serious activity that does not have frustrating consequences for those who play, in the sense of seeing error as something definitive and insurmountable. (Smolle \& Diniz, 2008, p.10)

The presence of the game will transform students' mistakes and failures into successes and victories, providing support for them to proceed with confidence towards the exploration of mathematics.

According to Smolle and Diniz (2008), the game has a function and as a consequence of this it brings the reduction of errors and failures.

Based on the authors' ideas, the game has a purpose and, consequently, it presents a reduction of frustrations, although the inclusion of the game during classes is not ruled out in order to facilitate the understanding of students.

For Lorenzato (2006), the key to students' school performance is the teacher. In order for the students' learning to become more effective, the teacher must have knowledge of the materials they will be using in the classroom, as they are instruments that will require specific knowledge for their handling.

The material that the teacher uses in the classroom must have a plan to be applied, so that it does not harm the students' performance. So, if the educator comes to use a didactic game to help in the development of his classes, he must be prepared to make the application, because the students will present doubts and these doubts will have to be answered, based on that, the students will be developing knowledge specific. 
Thus, the math teacher, when planning his class, needs to ask himself: is it convenient, or even necessary, to facilitate learning with some didactic material? Which one? In other words, the teacher is answering the questions: "Why didactic material?" and "When do you use it?". Then, you need to ask yourself, "How should this material be used?" (Lorenzato, 2006, p.24)

In addition to the teacher having a plan for his classes, he must discover methods that facilitate this understanding of the contents to be assimilated by the students and, consequently, he will have to prepare appropriate materials according to the students' knowledge.

The qualitative analysis will be carried out by observations through the students' behavior regarding the game's development and by records of the discussions during the game.

The quantitative analysis will be done according to data based on the students' understanding of the game, which will be collected through the application of a pre-test questionnaire and another post-test.

\section{Methodology}

It is a qualitative and quantitative research, applied at Colégio Ten. Rêgo Barros, in the classes of the sixth and ninth year of elementary school II, in the morning, from March to June 2016.

Pereira, A. S., et al. (2018). It was used as a research source used in this article as formatting and indication of the means and ways of correction.

The instrument used to obtain the information were tasks performed in the classroom with the students, using cardboard material and exposure to the blackboard by the students investigated under the guidance of the research professors. At the end of the research, a structured questionnaire was also made up, consisting of 5 questions used to outline a profile of the tasks and also the acceptance of them regarding aspects related to learning.

\subsection{A game developed for 6 th / 9 th grade students}

This game is called "The Awakening of Mathematics". It was a game developed for 6th / 9th grade students to solve such difficulties that some students were presenting during math classes.

\section{2 - Content}

- Addition, subtraction, multiplication and division of natural numbers.

- Mental calculation of addition, subtraction, multiplication and division with natural numbers.

- Development of logical reasoning.

\section{3 - Materials required}

- A whiteboard or blackboard.

- Quadrangular pieces of cardboard, cardboard, A4 paper or students' notebook.

- Pen, ballpoint pen or pencil.

\section{4 - Development of the game}

- The teacher will form 8 teams, with 4 students in each team.

- Each member of the team will have a mathematical operation for the construction of the board.

- The members of each team talked to each other to check which members have facilities for solving the multiplication tables on the board. 
- The member who is able to assimilate the calculations should keep the division, as this operation requires a certain mathematical knowledge.

- Each team will be named (may be called team A, B, C and D).

- Each member of each team will draw on their cardboard, cardboard, A4 paper or notebook the square 9x9 board (9 squares in height and width), containing a total of 81 squares on the board.

- The board can take on any size, however, the larger the board the larger the spaces to be filled.

- Teams will list the board with the natural numbers from 0 to 8 from right to left, example

Figure 1: Board Proposal.

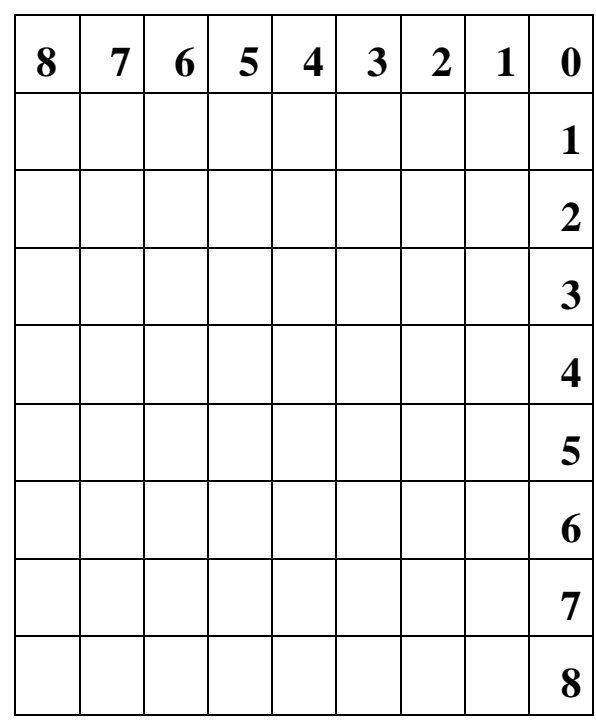

Source: Authors.

The calculation on the board will always be performed from right to left and will start when we take the second number on the right side of the board that is in the first row of the horizontal (number 1) and apply the operations with all the numbers that are in the first line vertically (numbers 1 through 8 ). Each number that is horizontal should follow the same concept.

Teams must have the respective results on their boards: 
a) Team A:

Figure 2: Activity proposal.

\begin{tabular}{|l|l|l|l|l|l|l|l|}
\hline $1+1=\mathbf{2}$ & $1+2=\mathbf{3}$ & $1+3=\mathbf{4}$ & $1+4=\mathbf{5}$ & $1+5=\mathbf{6}$ & $1+6=\mathbf{7}$ & $1+7=\mathbf{8}$ & $1+8=\mathbf{9}$ \\
\hline $2+1=\mathbf{3}$ & $2+2=\mathbf{4}$ & $2+3=\mathbf{5}$ & $2+4=\mathbf{6}$ & $2+5=\mathbf{7}$ & $2+6=\mathbf{8}$ & $2+7=\mathbf{9}$ & $2+8=\mathbf{1 0}$ \\
\hline $3+1=\mathbf{4}$ & $3+2=\mathbf{5}$ & $3+3=\mathbf{6}$ & $3+4=7$ & $3+5=\mathbf{8}$ & $3+6=\mathbf{9}$ & $3+7=\mathbf{1 0}$ & $3+8=\mathbf{1 1}$ \\
\hline $4+1=\mathbf{5}$ & $4+2=\mathbf{6}$ & $4+3=7$ & $4+4=\mathbf{8}$ & $4+5=\mathbf{9}$ & $4+6=\mathbf{1 0}$ & $4+7=\mathbf{1 1}$ & $4+8=\mathbf{1 2}$ \\
\hline $5+1=\mathbf{6}$ & $5+2=\mathbf{7}$ & $5+3=\mathbf{8}$ & $5+4=\mathbf{9}$ & $5+5=\mathbf{1 0}$ & $5+6=\mathbf{1 1}$ & $5+7=\mathbf{1 2}$ & $5+8=\mathbf{1 3}$ \\
\hline $6+1=\mathbf{7}$ & $6+2=\mathbf{8}$ & $6+3=\mathbf{9}$ & $6+4=\mathbf{1 0}$ & $6+5=\mathbf{1 1}$ & $6+6=\mathbf{1 2}$ & $6+7=\mathbf{1 3}$ & $6+8=\mathbf{1 4}$ \\
\hline $7+1=\mathbf{8}$ & $7+2=\mathbf{9}$ & $7+3=\mathbf{1 0}$ & $7+4=\mathbf{1 1}$ & $7+5=\mathbf{1 2}$ & $7+6=\mathbf{1 3}$ & $7+7=\mathbf{1 4}$ & $7+8=\mathbf{1 5}$ \\
\hline $8+1=\mathbf{9}$ & $8+2=\mathbf{1 0}$ & $8+3=\mathbf{1 1}$ & $8+4=\mathbf{1 2}$ & $8+5=\mathbf{1 3}$ & $8+6=\mathbf{1 4}$ & $8+7=\mathbf{1 5}$ & $8+8=\mathbf{1 6}$ \\
\hline
\end{tabular}

Source: Authors.

b) Team B:

Figure 3: Activity proposal.

\begin{tabular}{|c|c|c|c|c|c|c|c|}
\hline $1-1=\mathbf{0}$ & $1-2=-1$ & $1-3=-2$ & $1-4=-3$ & $1-5=-4$ & $1-6=-5$ & $1-7=-6$ & $1-8=-7$ \\
\hline $2-1=1$ & $2-2=\mathbf{0}$ & $2-3=-1$ & $2-4=-2$ & $2-5=-3$ & $2-6=-4$ & $2-7=-5$ & $2-8=-6$ \\
\hline $3-1=2$ & $3-2=1$ & $3-3=\mathbf{0}$ & $3-4=-1$ & $3-5=-2$ & $3-6=-3$ & $3-7=-4$ & $3-8=-5$ \\
\hline $4-1=3$ & $4-2=2$ & $4-3=1$ & $4-4=0$ & $4-5=-1$ & $4-6=-2$ & $4-7=-3$ & $4-8=-4$ \\
\hline $5-1=4$ & $5-2=3$ & $5-3=2$ & $5-4=1$ & $5-5=0$ & $5-6=-1$ & $5-7=-2$ & $5-8=-3$ \\
\hline $6-1=5$ & $6-2=4$ & $6-3=3$ & $6-4=2$ & $6-5=1$ & $6-6=0$ & $6-7=-1$ & $6-8=-2$ \\
\hline $7-1=6$ & $7-2=5$ & $7-3=4$ & $7-4=3$ & $7-5=2$ & $7-6=1$ & $7-7=\mathbf{0}$ & $7-8=-1$ \\
\hline $8-1=7$ & $8-2=6$ & $8-3=5$ & $8-4=4$ & $8-5=\mathbf{3}$ & $8-6=2$ & $8-7=1$ & $8-8=0$ \\
\hline
\end{tabular}


c) Team C:

Figure 4: Activity proposal.

\begin{tabular}{|l|l|l|l|l|l|l|l|l|}
\hline $1 \times 1=\mathbf{1}$ & $1 \times 2=\mathbf{2}$ & $1 \times 3=\mathbf{3}$ & $1 \times 4=\mathbf{4}$ & $1 \times 5=\mathbf{5}$ & $1 \times 6=\mathbf{6}$ & $1 \times 7=7$ & $1 \times 8=\mathbf{8}$ \\
\hline $2 \times 1=\mathbf{2}$ & $2 \times 2=\mathbf{4}$ & $2 \times 3=\mathbf{6}$ & $2 \times 4=\mathbf{8}$ & $2 \times 5=\mathbf{1 0}$ & $2 \times 6=\mathbf{1 2}$ & $2 \times 7=\mathbf{1 4}$ & $2 \times 8=\mathbf{1 6}$ \\
\hline $3 \times 1=\mathbf{3}$ & $3 \times 2=\mathbf{6}$ & $3 \times 3=\mathbf{9}$ & $3 \times 4=\mathbf{1 2}$ & $3 \times 5=\mathbf{1 5}$ & $3 \times 6=\mathbf{1 8}$ & $3 \times 7=\mathbf{2 1}$ & $3 \times 8=\mathbf{2 4}$ \\
\hline $4 \times 1=\mathbf{4}$ & $4 \times 2=\mathbf{8}$ & $4 \times 3=\mathbf{1 2}$ & $4 \times 4=\mathbf{1 6}$ & $4 \times 5=\mathbf{2 0}$ & $4 \times 6=\mathbf{2 4}$ & $4 \times 7=\mathbf{2 8}$ & $4 \times 8=\mathbf{3 2}$ \\
\hline $5 \times 1=\mathbf{5}$ & $5 \times 2=\mathbf{1 0}$ & $5 \times 3=\mathbf{1 5}$ & $5 \times 4=\mathbf{2 0}$ & $5 \times 5=\mathbf{2 5}$ & $5 \times 6=\mathbf{3 0}$ & $5 \times 7=\mathbf{3 5}$ & $5 \times 8=\mathbf{4 0}$ \\
\hline $6 \times 1=\mathbf{6}$ & $6 \times 2=\mathbf{1 2}$ & $6 \times 3=\mathbf{1 8}$ & $6 \times 4=\mathbf{2 4}$ & $6 \times 5=\mathbf{3 0}$ & $6 \times 6=\mathbf{3 6}$ & $6 \times 7=\mathbf{4 2}$ & $6 \times 8=\mathbf{4 8}$ \\
\hline $7 \times 1=7$ & $7 \times 2=\mathbf{1 4}$ & $7 \times 3=\mathbf{2 1}$ & $7 \times 4=\mathbf{2 8}$ & $7 \times 5=\mathbf{3 5}$ & $7 \times 6=\mathbf{4 2}$ & $7 \times 7=\mathbf{4 9}$ & $7 \times 8=\mathbf{5 6}$ \\
\hline
\end{tabular}

d) Team D:

Figure 5: Activity proposal.

\begin{tabular}{|l|l|l|l|l|l|l|l|}
\hline $1: 1=\mathbf{1}$ & $1: 2=\mathbf{0 , 5}$ & $1: 3=\mathbf{0 , 3 3 3}$ & $1: 4=\mathbf{0 , 2 5}$ & $1: 5=\mathbf{0 , 2}$ & $1: 6=\mathbf{1 , 1 6 6 6}$ & $1: 7=\mathbf{0 , 1 4 2}$ & $1: 8=\mathbf{0 , 1 2 5}$ \\
\hline $2: 1=\mathbf{2}$ & $2: 2=\mathbf{1}$ & $2: 3=\mathbf{0 , 6 6 6}$ & $2: 4=\mathbf{0 , 5}$ & $2: 5=\mathbf{0 , 4}$ & $2: 6=\mathbf{0 , 3 3 3}$ & $2: 7=\mathbf{0 , 2 8 5}$ & $2: 8=\mathbf{0 , 2 5}$ \\
\hline $3: 1=\mathbf{3}$ & $3: 2=\mathbf{1 , 5}$ & $3: 3=\mathbf{1}$ & $3: 4=\mathbf{0 , 7 5}$ & $3: 5=\mathbf{0 , 6}$ & $3: 6=\mathbf{0 , 5}$ & $3: 7=\mathbf{0 , 4 2 8}$ & $3: 8=\mathbf{0 , 3 7 5}$ \\
\hline $4: 1=\mathbf{4}$ & $4: 2=\mathbf{2}$ & $4: 3=\mathbf{1 , 3 3 3}$ & $4: 4=\mathbf{1}$ & $4: 5=\mathbf{0 , 8}$ & $4: 6=\mathbf{0 , 6 6 6}$ & $4: 7=\mathbf{0 , 5 7 1}$ & $4: 8=\mathbf{0 , 5}$ \\
\hline $5: 1=\mathbf{5}$ & $5: 2=\mathbf{2 , 5}$ & $5: 3=\mathbf{1 , 6 6 6}$ & $5: 4=\mathbf{1 , 2 5}$ & $5: 5=\mathbf{1}$ & $5: 6=\mathbf{0 , 8 3 3 3}$ & $5: 7=\mathbf{0 , 7 1 4}$ & $5: 8=\mathbf{0 , 6 2 5}$ \\
\hline $6: 1=\mathbf{6}$ & $6: 2=\mathbf{3}$ & $6: 3=\mathbf{2}$ & $6: 4=\mathbf{1 , 5}$ & $6: 5=\mathbf{1 , 2}$ & $6: 6=\mathbf{1}$ & $6: 7=\mathbf{0 , 8 5 7}$ & $6: 8=\mathbf{0 , 7 5}$ \\
\hline $7: 1=\mathbf{7}$ & $7: 2=\mathbf{3 , \mathbf { 5 }}$ & $7: 3=\mathbf{2 , 3 3 3}$ & $7: 4=\mathbf{1 , 7 5}$ & $7: 5=\mathbf{1 , 4}$ & $7: 6=\mathbf{1 , 1 6 6 6}$ & $7: 7=\mathbf{1}$ & $7: 8=\mathbf{0 , 8 7 5}$ \\
\hline $8: 1=\mathbf{8}$ & $8: 2=\mathbf{4}$ & $8: 3=\mathbf{2 , 6 6 6}$ & $8: 4=\mathbf{2}$ & $8: 5=\mathbf{1 , 6}$ & $8: 6=\mathbf{1 , 3 3 3}$ & $8: 7=\mathbf{1 , 1 4 2}$ & $8: 8=\mathbf{1}$ \\
\hline
\end{tabular}

Source: Authors.

Only the teacher will have knowledge of these tables with the results, the students will have to perform the calculation to discover the respective results.

The teacher will estimate a time of 20 minutes for the teams to develop the calculation on the board.

Before starting the game, some rules must be established: 
a) The team that wins the most rounds wins.

b) There will be a total of 4 rounds and in each round the teams must develop the multiplication table on the board.

c) Each round will have a time of 5 minutes to be completed.

d) The team that first announces that the boards are complete wins the round, but if at least one member has the board with the incorrect result, the whole team will be disqualified.

e) If the estimated time runs out and no team is finished, the teacher must take into account the students' work for completing the board, so if all the students have done something on their boards, everyone has won. And it will be up to the teacher to start a new round.

f) For each round that passes, the teacher will ask students to clear the results from the board to start the new round.

g) As the members finish filling out their board, they should help the other member of their team to complete the results.

h) As the rounds progress, the estimated time for completion of the results on the board will decrease (it will start with $5 \mathrm{~min}$.; $4 \mathrm{~min}$.; $3 \mathrm{~min}$.; $2 \mathrm{~min}$.)

i) If in each round (4 rounds) a different team wins, the teacher will take as a tiebreaker a new and only round, however, in this new round each team will make its best player available.

j) The teacher will estimate a time of 2 minutes for the players to plan on the board. The player who first presents the correct results on the board will be the champion along with his team.

1) At the end of the game, the teacher will have to present the winning students with sweets.

Observations: If there are not 32 students in the class to apply the game, there will be no problem if one of the teams assumes a greater or lesser number of players. The important thing is that the division is present in all teams

The teacher will have to help the division team in the construction of the results and will assume up to three places after the comma as a result, example: 1,$222 ; 1,333$.

If necessary, before starting the game the teacher will remind the students how to divide the divisor by being greater than the dividend, example: $1: 2=0.5$.

\section{Research Context}

The results were significant in the 6th grade / 9 class, where the game was applied, there was a significant improvement in learning, since, at the moment we finished the application of the game, some students mentioned that they would apply the game in their daily lives

The game was well courted by the students, everyone was very excited about the idea of having a didactic game as a member of the class, at first, they were a little scared because they had never played during classes, but during the presentation of the game they went releasing.

After the first moment, the students were getting used to the idea of the game and their spirits were already excited, nothing else that could hinder their performance and everyone made their dedication available for the progress of the didactic game.

The expectation that we created during the presentation of the rules of the game "the awakening of mathematics" was quite interesting, the students were so enthusiastic that they asked if they could already start filling the board without even knowing what it was to do.

During the application, the students were exchanging information and the pleasure of participating in that Interdisciplinary class with the mathematical game was always exuberant. 
When we presented the post-test questionnaire to the students, it was informed that there would be no need to put the name, because the data would be collected anonymously, more to our surprise some students informed that they would put the name on the questionnaire, because they had liked it too much of the game and wanted to be remembered for the positive comments about the game.

When we finished the game and we thanked the participation and dedication of all the majority of the students started to manifest themselves shouting for us not to leave, that due to the high performance that the game proposed to the students they did not want that magic moment to end. Thus, we answered that the game would never end, it would be enough for them to apply this game both in their daily lives and in the classroom.

After the students' frustration regarding the end of the game, we were surrounded by some students expressing their opinions about the game.

Speech by student A: “Uncle, I thought this game was great, I had never played using mathematics”.

Student B says: "When are we going to play again? Why I had never had an experience like this

Student C speaks: "Uncle, I already know how to use this game at my home”.

Student D says: "Uncles, are you going to be our teachers next year so we can play again? ".

The teacher who was present in the classroom during the application of the mathematical game expressed her opinion.

Teacher report: "It was through the game that the student with difficulty started to interact with the most intimate aspects of his personality, exploring objects that surround him, experiencing his senses, improving his agility, developing his thoughts, working on his self-esteem. The exchange of the evaluation for the game motivated the students and made them develop the need to have competence and sensitivity in face of the exposed content. It is extremely motivating and very efficient in learning".

Figure 6: We present the board to be designed by the students.

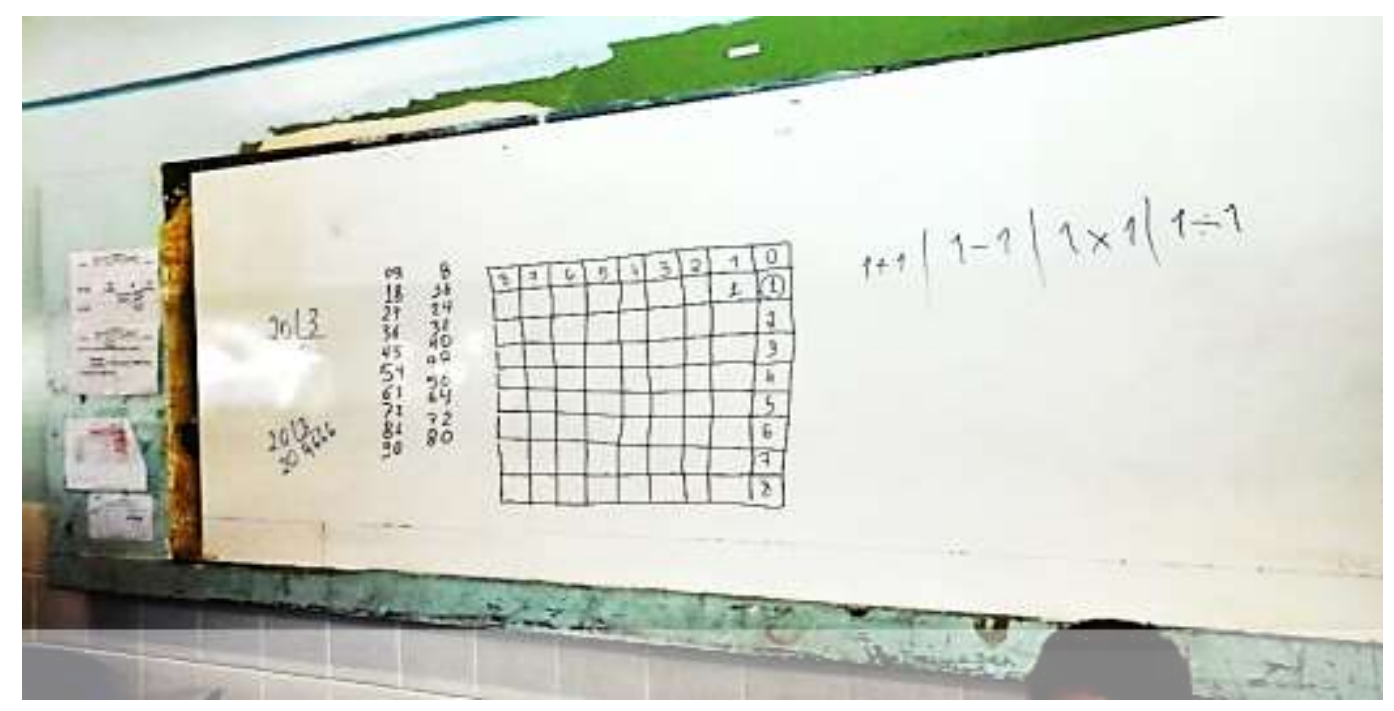

Source: Authors.

In this photo, we present the board to be designed by the students and explain the rules of the game on October 19 , 2016, at 7:30 am at the Tenente Rêgo Barros School. 


\section{Results}

To make the assessment, we drew a bar graph with some of the questions that were asked in the post-test questionnaire and the answer is yes or no, if the game was attractive; if there was anything interesting at the beginning of the game that captured my attention; the variation (in content or activity) helped to keep me tuned in to the game; the content of the game is relevant to my interests.

According to the data survey: 28 answered that yes, the game is attractive (the student made a comment regarding the question: "Yes, it is very cool") and 4 answered that no, it was attractive; 22 answered yes, there was something interesting at the beginning of the game that captured my attention (the student made a comment regarding the question: "Yes, the way we have to run the game" and 10 answered that no, there was something interesting at the beginning the game that captured my attention; 27 responded that yes, the variation (in content or activity) helped to keep me attentive to the game and 5 answered that no, the variation (in content or activity) did not help to keep me attentive to the game; 24 replied that yes, the content of the game is relevant to my interests (the student made a comment regarding the question: "Yes, because it helped me to exercise my mental capacity", and 8 replied that no, the content of the game did not is relevant to my interests.

Figure 7: Graph 1 - Evaluation of some questions that were asked in the questionnaire.

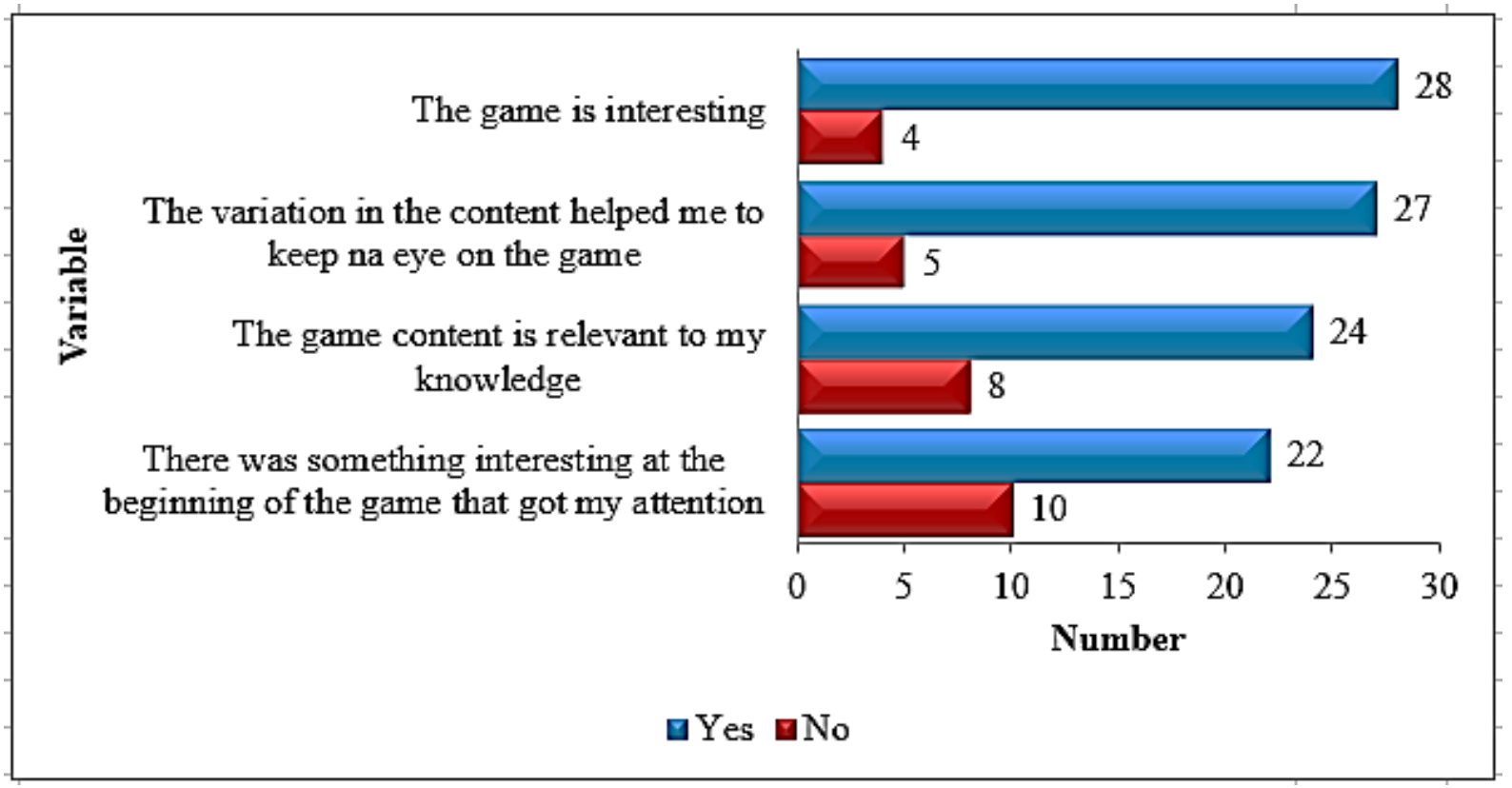

Source: Authors.

These questions, which were assessed through the questionnaire, were applied to find out what the students' performance was through using the game as a teaching resource. However, a bar chart has been sketched to give a more accurate assessment of student performance.

For the second graph, other questions were added: temporarily I forgot my day-to-day concerns, I was totally focused on the game; I didn't notice the time passing while playing, when I saw the game it was over; I am satisfied because I know that I will have the opportunity to use in practice, things I learned from the game; going through the stages of the game Ifelt confident that I was learning.

According to the data survey, 22 replied that yes, I temporarily forgot my day-to-day concerns, I was totally focused on the game (the student made a comment regarding the question: 
"Yes it was really good. Since I have personal problems" and 10 replied that no, temporarily I forgot my day-to-day concerns, I was totally focused on the game; 25 replied that yes, I did not notice the time passing while playing, when I saw the game it ended: (the student made a comment regarding the question "Yes, I relax a lot") and 7 replied that no, I did not notice the time passing while playing, when I saw the game it was over; 27 replied that yes, I am satisfied because I know that I will have the opportunity to use in practice, things that I learned from the game and 5 replied that no, I am satisfied because I know that I will have the opportunity to use in practice, things that I learned with the game; 29 answered yes, when going through the stages of the game I felt confident that I was learning and 3 said no, when passing through the stages of the game I felt confident that I was learning.

Figure 8: Graph 2 - Evaluation of some questions that were also asked in the questionnaire.

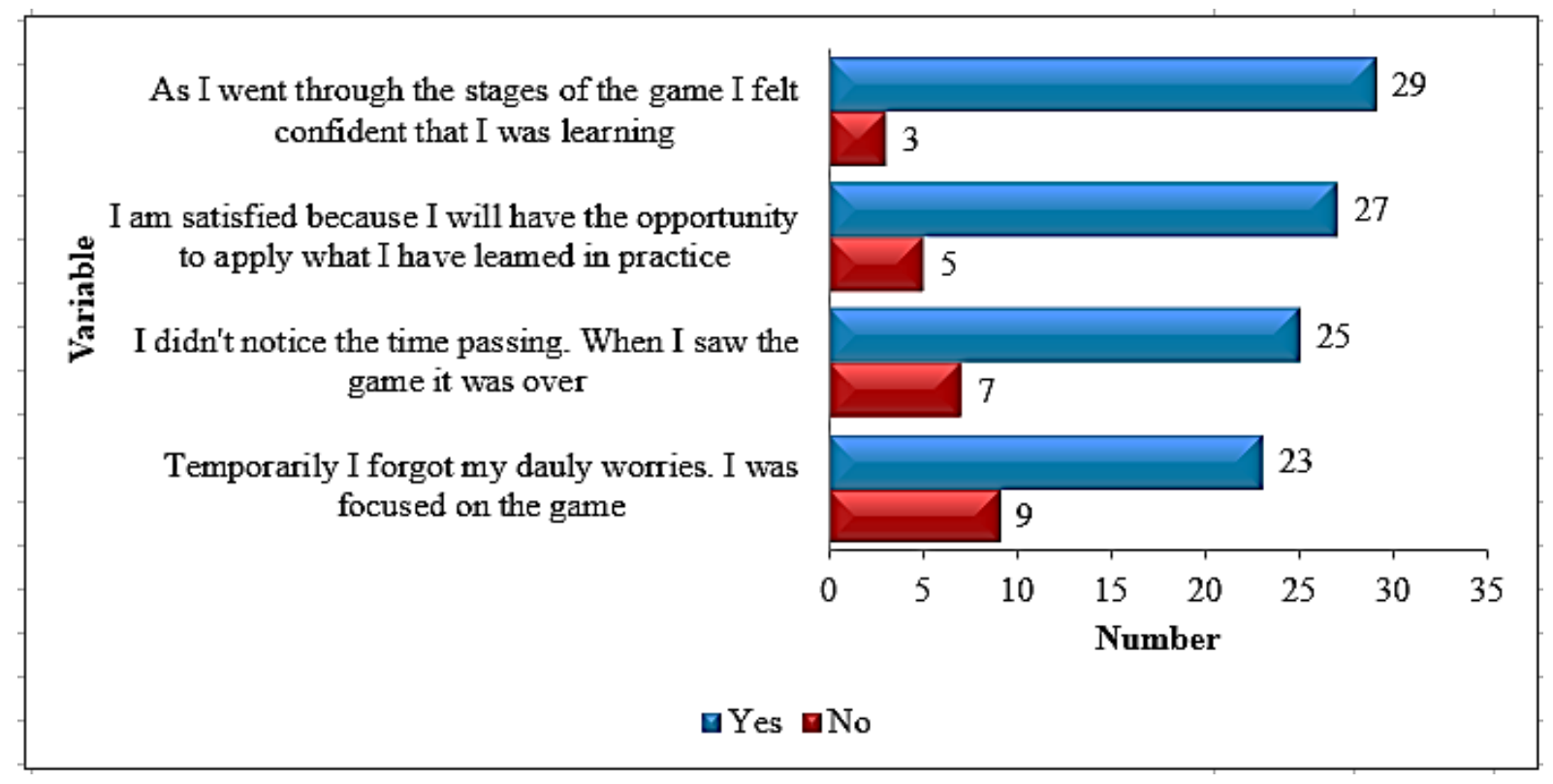

Source: Authors.

In the second graph we also have some of the questions that were asked in the questionnaire to assess the students' performance through the use of the game as a didactic resource. However, we can see that the students' performance has a positive balance.

In the same questionnaire, we asked to mention three strengths. The students mentioned some points, such as:

- "Competitiveness between teams".

- "Team work".

- "Making me develop math better".

- "Develops student learning".

- "It helped to exercise my mental capacity".

- "Arouses interest in mathematics".

- "The way you use math in the game".

- "Concentration".

In the same questionnaire, we asked to mention three suggestions for improving the game. The students mentioned some points, such as: 
- "I think there could be more time for division".

- "It should be with more numbers and involve other calculations".

- "It could contain square root".

- "For me the game is great as it is".

- "Increase up to 10 columns, and more time to respond".

• "Have more time and earn points".

\section{Final Considerations}

It was possible to observe that the game "the awakening of mathematics" increased the students' motivation for mathematics, making them start to see classes as a pleasant class. Our first experience using a mathematical game as a didactic resource, presented itself in a satisfactory way, as it was proven that the learning process was favored from the handling of the game during class.

One of the observations to be made is that the use of the game should not be applied only as a means of interaction between students, therefore, if the teacher proposes the game as a teaching strategy, he should treat it as a construction vehicle knowledge, creation and experimentation.

The work developed at the Tenente Rêgo Barros School proposed to students a development in learning, thus improving the motivation of some students who had let themselves be carried away by the difficulties that mathematics applied in their paths. The game caused an internal conflict in the children, who learned to deal with the frustrations that occur in their daily lives.

Every game must have clear rules so that the required goals can be achieved and the player can outline his strategies. Strategies, decision making, error analysis, the ability to deal with losses and gains are fundamental principles for the development of students' logical reasoning and cognitive structures.

Mathematics is a discipline in which students are not attracted, but with the application of various resources (games, modeling, others) they will be able to learn what is taught.

In addition to the game being a pleasurable activity in which students can interact, the game develops skills of group interaction, reasoning, motivation and helps to deal with frustrations, especially in relation to the low performance of students.

The teaching of mathematics must prioritize the advancement of the student's development in the face of significant learning situations, and teaching through games should happen as a resource to assist the teaching of content, enabling the acquisition of skills and the development of the student, removing the traditional method of tiring math classes for both the teacher and the student.

The game that the teacher proposes as a didactic resource to assist in the content must be educational, where students can learn from their mistakes and their victories. Therefore, mathematical games require an action plan that allows the learning of mathematical concepts and cultures in general. Since games are important in the classroom, we should use a schedule within math classes so that the teacher can explore the full potential of the game and especially the student's development.

We hope that the game "the awakening of mathematics" has not only contributed to making the students' learning process effective, but to show all educators how the use of didactic resources during classes is of fundamental importance.

This work serves as a reference for future applications in games for both 6th and 9th grades of elementary school as well as for other grades. It sets a precedent for new research on the four fundamental operations and how to make use of fruitful strategies for their development. 
Research, Society and Development, v. 10, n. 1, e37110111878, 2021

(CC BY 4.0) | ISSN 2525-3409 | DOI: http://dx.doi.org/10.33448/rsd-v10i1.11878

\section{References}

Batllori, J. (2006). Jogos para treinar o cérebro. Tradução de Fina Iñiguez: Madras.

Brito, M. R. F. (org). (2005). Psicologia da educação matemática: Teoria e pesquisa: Insular.

Dewey, J. (1952). Como pensamos: Companhia Editora Nacional.

Ferrari, M. (2004). Educadores que mudaram o pensar educacional, Revista Nova Escola, Editora Abril.

Kami, C., \& Declark, G. (1992). Reinventando a aritmética: implicações da teoria de Piaget: Papirus.

Kishimoto, T. M. (1996). Jogo, brinquedo, brincadeira e a educação. (3ª ed.): Cortez.

Leontiev, A. N. (1988).Uma contribuição à teoria do desenvolvimento da psique infantil: Ícone.

Lorenzato, S. (org). (2006).O Laboratório de Ensino da Matemática na formação de professores. Autores Associados.

Moyles, J. R. (2002). Só brincar? O papel do brincar na educação infantil. Tradução: Maria Adriana Veronese: Artmed.

Miranda. A. S. (2001). Uma proposta de aprendizagem siguinificativa de matemática através de jogos. São Paulo, FTD.

Pereira, A. S., et al.(2018). Metodologia da pesquisa científica. [e-book]. Santa Maria. Ed. UAB/NTE/UFSM.

Piaget, J. (1976). A formação do símbolo na criança: imitação, jogo, imagem e representação: Zahar.

Smole, K. S., \& Diniz, E. M. (2008). Jogos de matemática de $6^{\circ}$ ao $9^{\circ}$ ano: Artmed.

Silveira, R. S, \& Barone, D. A. C. (1998). Jogos Educativos computadorizados utilizando a abordagem de algoritmos genéticos. Universidade Federal do Rio Grande do Sul. Instituto de Informática. Curso de Pós-Graduação em Ciências da Computação.

Tahan, M. (1968). O homem que calculava: Record.

Vygotsky, L. S. (2007). A formação social da mente: Fontes. 